\title{
The Change in The Activity of The American Intelligence Services in The Security Context of the Last 24 Years.
}

\author{
Marian Zidaru ${ }^{1}$, Stefan Georgescu ${ }^{2}$, Cristi Dragan ${ }^{3}$
}

\begin{abstract}
The dynamic of the security events poses an overwhelming challenge for the decision makers' political agenda and priorities. The wide range of risks and the rhythm of the significant security events determine a difficult enterprise for security theories. A scientific analysis of the security evolutions entails a profound historical introspection and an appropriate understanding of the security events with significant impact over the global evolutions.

Probably in the next period of time, hundreds of papers will be written regarding the period since $9 / 11$. The aim of this paper is to provide a perspective over the security context, and the American intelligence services activity over the last 24 years, period of time dramatically divided by the unprecedented shock and suffering in the history from $9 / 11$.
\end{abstract}

\footnotetext{
Associated Professor, Phd, University Andrei Saguna Constanta tellephone+40745867803 (marian.zidaru@yahoo.com).

${ }^{2}$ Lecturer, Phd, University Andrei Saguna Constanta tellephone+40744368263

(stefan102001@yahoo.com)

${ }^{3}$ Lecturer, Phd, Maritime University Constanta tellephone+40744859745
} 
The reorganization of the American Intelligence Community was ordered as a result of the September 11th attacks and with future counterterrorism efforts in mind. Specifically, the 9/11 terrorists exploited the wall between the U.S.'s foreign and domestic intelligence collection efforts, and yet the IRTPA and EO 12333 avoided the issue of how to best integrate foreign and domestic intelligence while minimizing the threat to civil liberties. This manner in which the United States separates its foreign and domestic intelligence collection is particularly exploitable by terrorists and non-state actors-those currently posing one of the most serious threats to international security. To ensure both the best intelligence integration possible as well as the defense of civil liberties, clear and sensible rules should be formed which dictate how intelligence from these two spheres is collected and in what way and at what level it is integrated and disseminated.

Keywords: September 11, 2001; globalization; intelligence; security environment; USA; Security, terrorism.

\section{0-1995: The End of the Cold War and Retrenchment}

The three years following the George Bush's administration saw profound changes in the world that had huge impacts on the Intelligence Community. In November 1989, the Berlin Wall came down and Germany began the process of reunification. The Communist regimes of Eastern Europe gave way to democratic rule. In August 1990, Iraq invaded Kuwait. Shortly thereafter, the Soviet Union began to break apart with many former Soviet Republics declaring independence. In early 1991, the United States together with NATO allies (and the agreement of the Soviet Union) invaded Kuwait to oust the occupying Iraqi forces with a fearsome display of modern weaponry. In December 1991, Communist rule ended in Russia ${ }^{4}$.

Some analyst began to question whether an intelligence capability was needed any longer; others asked for significant retrenchment. Leaders within the Intelligence Community began streamlining their agencies and reorienting towards new missions, with a greater focus on transnational threats. Congress pushed them along by proposing a new Intelligence Community structure, and mandating across-the-board reductions in personnel.

The period ended with new spy cases at the CIA and FBI and renewed calls for reform.

\footnotetext{
${ }^{4}$ The Evolution of the U.S. Intelligence Community-An Historical Overview, http://www.fas.org/irp/offdocs/int022.html accesed at 02.04.2014.
} 


\section{The Gulf War}

The Gulf War from 1991 had significant repercussions for U.S. intelligence ${ }^{5}$. So much information had never been conveyed so fast from intelligence systems to warfighters with such devastating effect. The accuracy of United States' precision guided weapons astounded the world. The war also highlighted the need for the United States to expand its own efforts to link intelligence systems with combat systems and to train military personnel to use these systems effectively. America perceived that the future of warfare would be battles fought at a distance between opposing forces, placing a premium on the availability of intelligence, on the nature and disposition of hostile forces.

The Gulf War shows problems with intelligence. Initially, the Intelligence Community was not very well prepared to support military operations in this area, but given time in the autumn and winter of 1990 to put together a capability, they did their jobs. The Joint Intelligence Center was established during the war with representation from the key intelligence agencies and provided a model of suplying crisis support to military operations. A permanent National Military Joint Intelligence Center was established shortly after the conflict at the Pentagon and later at all unified commands. The war illuminated problems in disseminating imagery to the field as well as the limitations of U.S. human intelligence capabilities. In addition, an important problem arose with competing intelligence agencies and military assessments of the damage caused by allied bombing.

\section{The Gates Task Forces}

In 1991, DCI Robert Gates undertook a strong reexamination of the post-Cold War Intelligence Community. The recommendations of 14 separate task forces produced important change: analysis must be made more responsive to decisionmakers; a formalized requirements process would be established for human source intelligence collection; new offices were created at the CIA to coordinate the use of publicly available ("so called open source") information and to improve CIA support to the Army. The staff of the DCI, that supported Gates in his Community role, was strengthened. And, after many negotiations about which entities to include, a new Central Imagery Office, under the joint control of the DCI and the Secretary of Defense, was established to coordinate imagery collection and uniform standards for the interpretation and dissemination of imagery to the field.

\footnotetext{
${ }^{5}$ Report on the Comission on the roles and capabilities of the United States Intelligence Community, Preparing for the 21st Century. An apraisal for US Intelligence, p. A 23. accesed at 02.04.2014.
} 


\section{Boren-McCurdy Legislation}

While the Gates' task forces were at work, the legislation was established by the respective Chairmen of the Senate and House intelligence committees to restructure the Intelligence Community. The bills called for the creation of a Director of the National Intelligence with authority over the intelligence budget as well as authority to transfer personnel temporarily from one intelligence agency to another. The DNI would continue to establish requirements and priorities for intelligence collection and serve as the President's intelligence adviser. In this regard, the analytical element of the CIA would be transferred under the control of the DNI, leaving the remainder that the CIA should be administered by a separate agency director. The legislation also proposed a National Imagery Agency to coordinate imagery tasking, collection, processing, and dissemination ${ }^{6}$.

Given the actions taken by DCI Gates to implement the results of his task forces, however, the committees did not push for enactment of their alternative proposals. Instead they opted to codify and to clarify the existing statutory framework that had been largely unchanged since 1947. The Intelligence Organization Act of 1992 (enacted as part of the Intelligence Authorization Act for 1993) defined for the first time the Intelligence Community by law, enunciated the three roles of the DCI, set forth the authorities and responsibilities of the DCI in relation to other elements of the Intelligence Community, and articulated the responsibilities of the Secretary of Defense for the execution of national intelligence programs. Among other things, the Secretary was requested to consult with the DCI prior to appoint the Directors of the NSA, the NRO, and the DIA ${ }^{7}$.

Congress continued to debate whether the intelligence budget should be declassified. In 1991 and 1992, Congress passed non-binding "Sense of Congress" resolutions urging the President to make public the aggregate funding for intelligence. President Bush declined to do so, as did President Clinton in 1993.

\section{The Vice President's National Performance Review}

In 1993, as part of the Clinton Administration's overall effort to "reinvent" the government, a team from the Vice President's National Performance Review looked at the

\footnotetext{
${ }^{6}$ Ibid. p. A24

${ }^{7}$ The Evolution of the U.S. Intelligence Community-An Historical Overview, http://www.fas.org/irp/offdocs/int022.html accesed at 03.04.2014.
} 
Intelligence Community and suggested that several actions be taken to consolidate activities and build a sense of Community in order to be more efficient and to better serve customers. The review found that the Community was too often drawn apart by the competition for new programs and budget allocations and recommended rotational assignments among agencies as a means of promoting a broader, more collegial perspective. The review's recommendation that the Intelligence Oversight Board be merged into the President's Foreign Intelligence Advisory Board was accomplished by Executive Order in September $1993^{8}$.

\section{The Ames Spy Case}

In February 1994, Aldrich H. Ames, a CIA employee with almost 30 years experience in operations, was charged with spying for the Soviet Union since at least 1985. During this period, he was alleged to have disclosed virtually all of the CIA's active Soviet agents, many of whom were later executed or imprisoned. In May, Ames and his wife pled guilty and were sent to prison.

The ensuing investigations by the CIA Inspector General and by the congressional intelligence committees reported that Ames had exhibited serious personal problems and a penchant for exorbitant spending which should have brought him under security scrutiny. The investigations also highlighted problems in coordinating counterintelligence cases between the FBI and the CIA. Notwithstanding the seriousness of Ames' disclosures and the many shortcomings on the part of CIA officers, DCI Woolsey meted out what were perceived as relatively mild disciplinary measures. The confidence of the public and the Congress in the CIA appeared considerably eroded.

In the fall of 1994, new legislation was enacted to improve counterintelligence and security practices across the Intelligence Community, and, in particular, to improve the coordination between the FBI and CIA. In addition, the President created a new bureaucratic framework for handling counterintelligence matters, to include the placement of FBI counterintelligence specialists within the CIA.

\section{The Creation of a New Commission}

Even before the Ames case provided the immediate impetus, the congressional intelligence committees anticipated that the Executive branch would conduct a comprehensive

\footnotetext{
${ }^{8}$ Report on the Comission on the roles and capabilities of the United States Intelligence Community, Preparing for the 21st Century. An apraisal for US Intelligence, p. 234. accesed at 02.04.2014.
} 
review of the Intelligence Community. When this failed to materialize, the Senate committee, and, in particular, its Vice Chairman, Senator John Warner, developed a legislation to establish a commission to study the roles and capabilities of intelligence agencies in the postCold War era, and to make recommendations for change. The legislation was approved in October 1994, as part of the Intelligence Authorization Act for $1995^{9}$.

\section{George J. Tenet 1997-2004}

George Tenet was appointed the Deputy Director of Central Intelligence in July 1995. After John Deutch's abrupt resignation in December 1996, Tenet served as acting director until he was officially appointed director on July 11, 1997, after a unanimous confirmation vote in the Senate. Tenet served past the end of the Clinton Administration and throughout the first term of George W. Bush.

Tenet embarked on a mission to regenerate the CIA, which had fallen on hard times since the end of the Cold War. The number of new trainee agents recruited each year had fallen to an all-time low, a 25-percent decline from the Cold War peak. Tenet appealed to the original mission of the agency, which had been to "prevent another Pearl Harbor". The problem was to foresee where danger might come from in the post-Cold War world. Tenet focused on potential problems such as "the transformation of Russia and China", "rogue states" like North Korea, Iran, and Iraq, and terrorism.

In 1999, Tenet put forward a grand plan for dealing with the al-Qaeda organization. This effort supposedly put the CIA in a better position to respond after the September 11, 2001 attacks.

On September 15, 2001, Tenet presented the Worldwide Attack Matrix, a blueprint for what became known as the War On Terror ${ }^{10}$. He proposed firstly to send CIA teams into Afghanistan to collect intelligence on, and mount covert operations against, al-Qaeda and the Taliban. The teams would act jointly with military Special Operations units. "President Bush later praised this proposal, saying it had been a turning point in his thinking."

\footnotetext{
${ }^{9}$ Intelligence Authorization Act for Fiscal Year 1995, http://en.wikisource.org/wiki/Intelligence_Authorization_Act_for_Fiscal_Year_1995 accesed at 03.04.2014.

${ }^{10}$ THE 9/11 COMMISSION REPORT, chapter 10 Wartime, http://www.911commission.gov/report/911Report_Ch10.pdf accesed at 03.04.2014.
} 
After the September 11, 2001 attacks, many observers criticized the American Intelligence Community for numerous "intelligence failures" as one of the major reasons why the attacks were not prevented. In August 2007, part of a secret report written by the CIA Inspector General was made public (originally written in 2005 but kept secret). Its 19-page summary states that Tenet knew the dangers of Al Qaeda well before September 2001, but that the leadership of the CIA did not do enough to prevent any attacks. Tenet reacted to the publication of this report by calling it "flat wrong".

Bob Woodward, in his book Plan of Attack, wrote that Tenet privately lent his personal authority to the intelligence reports about weapons of mass destruction (WMDs) in Iraq. At a meeting on December 12, 2002, he assured Bush that the evidence against Saddam Hussein amounted to a "slam dunk case". After several months of refusing to confirm this statement, Tenet later stated that this remark was taken out of context. (Tenet indicated that the comment was made pursuant to a discussion about how to convince the American people to support the invasion of Iraq, and that, in his opinion, the best way to convince the people would be by explaining the dangers posed by Iraq's WMD i.e., the public relations sale of the war via the WMD, according to Tenet, would be a "slam dunk".) The search following the 2003 invasion of Iraq by American, British, and other international forces yielded no stockpiles of WMDs in Iraq. Tenet and his Director of Operations resigned at about this same time, and it has been suggested that these resignations were in penance over the WMD issue in Iraq.

\section{Porter J. Goss 2004-2005}

During his junior year at Yale, Porter Goss was recruited by the CIA ${ }^{11}$. During 19601971 he worked for the Directorate of Operations, the clandestine branch of the CIA. There, he first worked in Latin America and the Caribbean region and later in Europe. Goss said that he has recruited and trained foreign agents, working in Miami for much of the time.

He was elected in Congress for 16 years, as a Republican House member from Florida, until his appointment as Director of the CIA. During this period, Goss defended the CIA activity and supported strong budget increases for the Agency, even during the Clintonian period in which the Administration slashes to other parts of the intelligence budgets. In mid-

\footnotetext{
${ }^{11}$ Dan Eggen And Walter Pincus, Porter Goss: Low-key Gives Way To Aggressive, http://articles.sunsentinel.com/2004-08-11/news/0408110072_1_porter-goss-house-intelligence-committee-cia accesed at 04.04.2014.
} 
2004, Goss took a very strong position, urging specific reforms and corrections in the way the CIA carried out its activities, lest it become "just another government bureaucracy ${ }^{12}$."

After growing pressure, Congress established the Joint Inquiry into Intelligence Community Activities before and after the Terrorist Attacks of September 11, 2001, a joint inquiry of the two intelligence committees, led by Goss and Senator Bob Graham. Goss and Graham made it clear that their goal was not to identify specific wrongdoing. The inquiry's final report was released in December 2002 and focused entirely on the FBI and CIA's activities, including no information on the White House's activities. Goss strongly blamed President Bill Clinton for the September 11 CIA failures.

Goss brought with him five personal staff members who were to implement change that became unpopular with CIA professionals. Steve Kappes-the Director of Operationsand his subordinates including Michael Sulick, Kappes' then-deputy, resigned early in Goss' tenure. Although Kappes came back to a responsible position, it has been reported that he rather quit the Agency than carry out a request by Goss to reassign Michael Sulick. Following Goss's departure, both Kappes and Sulick have returned to positions of higher authority in the U.S. Intelligence Community. Kappes as the Deputy Director of the CIA and Sulick was appointed Director of the National Clandestine Service on September 14, 2007.

Speculations on the reason for his departure include a desire to have military agency heads, or, perhaps more likely ${ }^{13}$. For many analysts, Goss' departure was inevitable, given the widespread perception that the White House had lost confidence in his ability to reorganise the CIA. Goss' departure appears to have been due, at least in part, to his repeated clashes with John Negroponte who was appointed in 2005 as the US Director of the National Intelligence, a new post created to coordinate all 16 of the US intelligence agencies in the aftermath of the Al-Qaeda attacks.

A claim regarding the existence of black sites was made by The Washington Post in November 2005 and before that, by human rights NGOs. US President George W. Bush acknowledged the existence of secret prisons operated by the CIA during a speech on September 6, 2006.

\footnotetext{
${ }^{12}$ Porter Goss: http://www.multiurl.com/s/03Or

13 Yet more turmoil at the CIA Jane's. 11 May 2006. accesed at 04.04.2014.
} 


\section{The reaction of the intelligence communities at radical Islamist propaganda.}

'They think they are the best in the world with their services: the CIA, MI6, MI5, or as they are called in the U.S. and in other parts of the world. They must understand that they are dealing with an ideology and the ideology that currently 1.6 billion people have is faster in the broadcast $^{14}$. The answer that intelligence communities have attempted to formulate along time with respect to the role of the Internet in the process of radicalization has not given the expected results. European States have adopted a series of policies which seek to limit the process of radicalization, the most interesting being the examples of Belgium, the Netherlands and Great Britain. In the Netherlands, the webmasters of sites that attract a large number of young Muslims, violent Jihad sympathizers, have implemented a system according to which radical expressions are replaced with moderate messages. Great Britain and Belgium make reference to the role of social accountability in the fight against radicalisation in the virtual environment ${ }^{15}$. Although there have been created a number of mechanisms whose primary objective is to investigate the internet sites that promote violence and extremism, citizens are encouraged to report such cases. Of course, that the literature of one of the strategies mentioned most often is the one that makes reference to the arguments against the use of violent Jihad (which gives a further explanation of Jihad type cut and paste) the dissemination and promotion of moderate imams's visions and accountability, giving priority to religious education. If the magazine Inspire talks about more de facto participates in an ideological recrutation' rather than in the operational one, phasing out the jihad ideology leading mentors, like Anwar al Awlaki or Osama bin Laden, did not affect their speech to radicalise. Furthermore, the action is described as a 'mistake' in the sense in which 'Obama's advisers do not know what they have to do. They don't know who they are fighting against. What you need to understand is that, even taken separately, the people will not stop calling to Islam. You must understand that they have to do with ideology ${ }^{16}$.

\footnotetext{
${ }^{14}$ British islamist abu Abdallah al-Britani, "The assassination of Anwar al Awlaki and Osama Bin Laden will not stop the spread of Islam" http://www.memrijttm.org/ accesed at 05.04.2014.

${ }^{15}$ Radicalisation: the role of the internet. Insitute for Strategic Dialogue, Stockholm, 2011 p. 8. (http://www.strategicdialogue.org/allnewmats/idandsc2011/StockholmPPN2011_BackgroundPaper_ FINAL.pdf). accesed at 06.04.2014.

${ }^{16}$ Johnny RYAN, Countering militant Islamist radicalisation on the internet: a user driven, IEA, 2007, pp.133-136. accesed at 06.04.2014.
} 
'The immigrant Muslim Declaration known under the pseudonym abu Abdallah alBritons comes to support an older comment posted on the internet in the assumption that leaders like Awlaki or Osama get just the message carriers of al-Islam, defending the lives of innocents and spreading the word of truth: 'even if we were to be killed (Awlaki) tomorrow in an air attack, we will join the classics, but also its recent brethren, Abdulah Azzam, Yusuf AlAyyiry giving evidence that it is not necessary to live among the unbelievers to be a imam of Islam $^{17}$. At that time he would be viewed as being the most popular preacher of Islam, speaker of English, and the whole world will listen to him and more ${ }^{\prime 18}$. At this level, the weight of the Act should be taken under consideration. The problem of ideology becomes difficult when even among Islamic moderates, who disapproves of terrorism, a consensus on the reasons for which it should be condemned cannot be reached. Some refer to the Sharia, the traditional Islamic jurisprudence, while others appeal to the fact that the etymology of the Word does not imply the meaning of 'holy war' or the one with military connotation ${ }^{19}$. In the absence of a clear, moderate and religious education, many reffer to the fatwa of jihad as a personal duty, encouraging radical Muslim immigrants living in Western societies to rethink their position in accordance with the Governments that have adopted them ${ }^{20}$.

Terrorism has found in the internet extraordinary means and operational and logistical support, to promote their interests, thus being the most used. For example, on January 27, 2013, on the Facebook account 'Taib Al Kalam Mina Ulama Ahl Al-Islam' (in translation, 'Talk of the nation Islamic theologians'), appeared a message posted in Arabic, written under the pseudonym 'Al-Islami Jinsiya' ('Muslim nationality'), containing references to future AlQaeda attacks, which are said to take place in France, Denmark, The U.S. and other countries in Europe. The post in question had the title Al-Qaeda and its future attacks '. The post was made to answer the question: 'Where will Al-Qaeda attack in the future? ... The following AlQaeda attacks will be launched, with the will of Allah, in the heart of the realm of unbelief,

\footnotetext{
${ }^{17}$ Jack, BARCLAY, 'Can Al-Qaeda Use Islam To Justify Jihad Against The United States? A debate In Progress', Jamestown Foundation Terrorism Monitor (Vol. 8, No. 25, July 2010).. p. 13. accesed at 06.04.2014.

${ }^{18}$ Daniela, SPÎNU, „Imigraţia musulmană şi identitatea naţionalăîn Europa. Împreună sau separaţi?” în Sfera Politicii, Vol.XIX, Nr.4 (158), pp. 83-93. accesed at 06.04.2014.

${ }^{19}$ VELDHUIS, Tinka, STAUN, Jørgen, Islamist Radicalisation. A root cause model, Institutul de Relaţii Internaţionale, Olanda, 2009. accesed at 06.04.2014.

${ }^{20}$ VIDINO, Lorenzo, Radicalization, Linkage and diversity. Currents Trends in Terrorism in Europe, RAND, 2011. accesed at 06.04.2014.
} 
the Americas, and in Denmark, France and other European countries, in those States which have supported and continue to support the French State, as well as in other locations. (...) The attacks will be serious, strong, alarming, shocking, disturbing and terrifying.

\section{Conclusions}

After 20 years from the collapse of the Communist regimes we are at the stage in which civil-military experts on one hand and policy makers on the other hand, seek common points of language in order to strengthen new security architecture. Redefining security, establishing the correct risk factors and threats and creating a new taxonomy of the field have become fundamental to the strategic approach for defense and security. The conceptual formula is the development in two directions, one intensive, extensive and one generated by the deepening of the study of security and increase coverage.

By increasing the coverage of the survey, the following are meant to be included: security and economic situation, the impact of domestic policy, as well as the international security institutions, in terms of preserving the State as essentially referential. Deepening the study takes into account the security of the individual's cognitive relevance of growth. The reorganization of the Western Intelligence Community was ordered as a result of the September 11th attacks and with future counterterrorism efforts in mind. Specifically, the 9/11 terrorists exploited the wall between the U.S.'s foreign and domestic intelligence collection efforts, and yet the IRTPA and EO 12333 avoid the issue of how to best integrate foreign and domestic intelligence while minimizing the threat to civil liberties. This manner in which the Western Countries separates its foreign and domestic intelligence collection is particularly exploitable by terrorists and non-state actors-those currently posing one of the most serious threats to international security. To ensure both the best intelligence integration possible as well as the defense of civil liberties, clear and sensible rules should be formed that dictate how intelligence from these two spheres is collected and in what way and at what level it is integrated and disseminated. 


\section{References}

1. BARCLAY, Jack, 'Can Al-Qaeda Use Islam To Justify Jihad

Against The United States? A debate In Progress', Jamestown Foundation Terrorism

Monitor (Vol. 8, No. 25, July 2010).. p. 13. accesed at 06.04.2014.

2. British islamist abu Abdallah al-Britani, "The assassination of Anwar al Awlaki and

Osama Bin Laden will not stop the spread of Islam" http://www.memrijttm.org/ accesed at 05.04.2014.

3. Eggen, Dan And Pincus, Walter, Porter Goss: Low-key Gives Way To Aggressive, http://articles.sun-sentinel.com/2004-08-11/news/0408110072_1_porter-goss-houseintelligence-committee-cia accesed at 04.04.2014.

4. Intelligence Authorization Act for Fiscal Year 1995, http://en.wikisource.org/wiki/Intelligence_Authorization_Act_for_Fiscal_Year_1995 accesed at 03.04.2014.

5. Radicalisation: the role of the internet. Insitute for Strategic Dialogue, Stockholm, 2011 p. 8.

(http://www.strategicdialogue.org/allnewmats/idandsc2011/StockholmPPN2011_Back groundPaper_FINAL.pdf). accesed at 06.04.2014.

6. Report on the Comission on the roles and capabilities of the United States Intelligence Community, Preparing for the 21st Century. An apraisal for US Intelligence, p. A 23. accesed at 02.04.2014.

7. RYAN, Johnny, Countering militant Islamist radicalisation on the internet: a user driven, IEA, 2007, pp.133-136. accesed at 06.04.2014.

8. SPÎNU, Daniela, „Imigraţia musulmană şi identitatea naţionalăîn Europa. Împreună sau separaţi?" în Sfera Politicii, Vol.XIX, Nr.4 (158), pp. 83-93. accesed at 06.04.2014.

9. The 9/11 Commission Report, chapter 10 Wartime, http://www.911commission.gov/report/911Report_Ch10.pdf accesed at 03.04.2014. 
10. The Evolution of the U.S. Intelligence Community-An Historical Overview, http://www.fas.org/irp/offdocs/int022.html accesed at 02.04.2014

11. VELDHUIS, Tinka, STAUN, Jørgen, Islamist Radicalisation. A root cause model, Institutul de Relaţii Internaţionale, Olanda, 2009. accesed at 06.04.2014.

12. VIDINO, Lorenzo, Radicalization, Linkage and diversity. Currents Trends in Terrorism in Europe, RAND, 2011. accesed at 06.04.2014

13. Yet more turmoil at the CIA Jane's. 11 May 2006. accesed at 04.04.2014. 